\title{
TINJAUAN TEORITIS PENGENDALIAN KUALITAS PRODUK HASIL INDUSTRI DENGAN METODE STATISTIK
}

\author{
L. Virginayoga Hignasari ${ }^{1}$ \\ ${ }^{1}$ Program Studi Teknik Industri, Universitas Mahendradatta \\ Jalan Ken Arok No 10-12, Denpasar \\ 1Email : ginahignasari@gmail.com
}

\begin{abstract}
Abstrak - Penelitian ini bertujuan untuk mengetahui proses pengendalian kualitas suatu produk industri dengan metode statistik secara teoritis. Penelitian ini merupakan penelitian kualitatif dengan metode studi pustaka. Data diperoleh dari beberapa penelitian yang mengambil sampel pada bidang industri barang. Data yang diperoleh kemudian dianalisis dan dijabarkan secara deskriptif. Kualitas suatu produk adalah salah satu dasar keputusan konsumen akan kepuasan pada produk yang mereka beli sesuai dengan keinginan dan harapannya. Pengendalian kualitas statistik merupakan teknik penyelesaian masalah yang digunakan sebagai pemonitor, pengendali, penganalisis, pengelola dan memperbaiki proses dengan menggunakan metode metode statistik. Adapun proses pengendalian kualitas suatu produk industri dengan metode statistik adalah sebagai berikut : 1) Membuat Chech Sheet, 2) Membuat Diagram Pareto, 3) Membuat Control Chart, 4) Membuat Diagram Sebab Akibat, 5) Membuat tabel Failure Mode Effect Anlaysis (FMEA).
\end{abstract}

Kata kunci : industri, pengendalian kualitas, produk, statistik

\begin{abstract}
Abtract - This study was aimed to determine the quality control process of an industrial product with theoretical statistical methods. This research was a qualitative research with literature study method. Data obtained from several studies that take samples in the field of goods industry. The data obtained was then analyzed and described descriptively. The quality of a product was one of the basic decisions of consumers to be satisfied with the products they buy according to their wishes and expectations. Statistical quality control was a problem solving technique that was used as a monitor, controller, analyzer, manager and improve the process by using statistical methods. The quality control process of an industrial product with statistical methods was as follows: 1) Made Chech Sheets, 2) Made Pareto Diagrams, 3) Made Control Charts, 4) Made Cause and Effect Diagrams, 5) Made Failure Mode Effect Anlaysis (FMEA) table.
\end{abstract}

Keywords: industry, quality control, products, statistics

\section{PENDAHULUAN}

Industri adalah salah satu penggerak perekonomian suatu negara. Di jaman milienial ini, kita berada pada generasi industri 4.0. Adapun Industri 4.0 lahir setelah didahului tiga generasi sebelumnya, yaitu generasi pertama mesin uap, generasi kedua elektrifikasi, dan generasi ketiga komputer. Generasi keempat atau industri 4.0 ialah era dimana segala aktivitas didominasi dengan sistem siber fisik (cyber physical system), dengan digitasi dan interkoneksi produk, rantai nilai (value chains) dan model bisnis. Industri 4.0 juga mencakup riset, jejaring pelaku industri, dan standardisasi (European Commission, Germany; Industrie 4.0, 2017). Dengan digitasi interkoneksi produk, mata rantai perdagangan dapat diperpendek sehingga mempercepat mobilitas arus barang dan jasa dari produsen ke konsumen.

Di era industri 4.0, untuk menjalankan sebuah industri, diperlukan perencanaan dan pelaksanaan yang tepat. Berbagai sektor harus diperhatikan agar sebuah industri dapat bertahan dan berkelanjutan. Berdasarkan jenisnya, bidang industri dibedakan menjadi dua, yaitu industri barang dan industri jasa. Industri barang merupakan usaha mengolah bahan mentah 
menjadi barang setengah jadi atau barang jadi. Kegiatan industri ini menghasilkan berbagai jenis barang, seperti pakaian, sepatu, mobil, sepeda motor, pupuk, dan obatobatan. Industri jasa merupakan kegiatan ekonomi yang dengan cara memberikan pelayanan jasa. Contohnya, jasa transportasi seperti angkutan bus, kereta api, penerbangan, dan pelayaran. Perusahaan jasa ada juga yang membantu proses produksi. Contohnya, jasa bank dan pergudangan. Pelayanan jasa ada yang langsung ditujukan kepada para konsumen. Contohnya asuransi, kesehatan, penjahit, pengacara, salon kecantikan, dan tukang cukur.

Dalam perencanaan suatu sistem baik dalam sistem kerja maupun industri, dibutuhkan teori dasar untuk merumuskan suatu sistem tersebut. Salah satu konsep dasar yang sangat berperan dalam perumusan konsep dalam bidang perencanaan dan pengendalian adalah matematika. Konsep matematika yang sangat berperan dan aplikatif di bidang industri diantaranya : konsep logika matematika, konsep kalkulus, teori graph, program linier, teori probabilitas, konsep statistika. Konsep-konsep tersebut pada dasarnya sangat berperan bidang analisis dan untuk membangun pola pikir agar dapat berpikir secara sistematis. Apabila terdapat permasalahan, masalah dapat dicarikan solusinya dengan menyusun strategi melalui pemodelan secara matematis dan sistematis. Menurut Sutrisno, Aplikasi Matematika di bidang Industri dapat digolongkan dalam dua kategori yaitu aplikasi matematika dalam pengembangan dan operasi teknologi dalam suatu industri dan aplikasi matematika di dalam menyelesaikan masalah dengan melakukan proses analisis (diagnostik) serta terapi yang disimpulkan dari hasil analisis (dalam Kartono, 2003).

Kualitas hasil produksi menjadi salah satu dasar keputusan konsumen akan kepuasan pada produk yang mereka beli sesuai dengan keinginan dan harapannya. Akibatnya kualitas merupakan faktor kunci yang membawa keberhasilan bisnis dan peningkatan posisi dalam bersaing. Program jaminan kualitas yang efektif dapat meningkatkan penetrasi pasar, produktivitas lebih tinggi dan biaya pembuatan barang dan jasa secara keseluruhan menjadi lebih rendah. Kualitas secara sederhana dapat diartikan sebagai suatu usaha memenuhi harapan konsumen, sehingga konsumen memegang peranan penting apakah produk tersebut berkualitas atau tidak. Kualitas suatu produk adalah keadaan fisik, fungsi dan sifat suatu produk bersangkutan yang dapat memenuhi selera dan kebutuhan konsumen dengan memuaskan sesuai dengan nilai uang yang dikeluarkan (Leavenworth 1998). Menurut (Montgomery 1990) kualitas adalah keseluruhan gambaran karakteristik produk dan jasa dalam pemasaran, rekayasa pembuatan dan pemeliharaan yang membuat produk dan jasa yang digunakan dapat memenuhi harapan konsumen. Sifat dan fungsi yang digunakan dalam menilai kualitas produk disebut sifat kualitas. Kualitas suatu produk merupakan keadaan fisik, fungsi dan sifat suatu produk bersangkutan yang dapat memenuhi selera dan kebutuhan konsumen dengan memuaskan sesuai dengan nilai uang yang dikeluarkan.

Berhasil atau tidaknya sebuah industri tergantung pada kualitas produk yang dihasilkan. Oleh sebab itu dalam menjaga setiap kualitas produk, harus dilaksanakan suatu monitoring yaitu pengendalian kualitas produk. Suatu proses yang tidak bisa dilewatkan oleh sebuah industri agar industri tersebut dapat tetap bertahan dan berkelanjutan. Proses pengendalian kualitas tersebut menggunakan konsep dan teori dasar matematika. Oleh sebab itu pada penelitian ini akan dijabarkan mengenai proses secara teoritis pengendalian kualitas produk hasil industri dengan metode statistik.

\section{METODE PENELITIAN}

Penelitian ini merupakan penelitian kualitatif dengan metode studi pustaka. Data diperoleh dari beberapa penelitian yang mengambil sampel pada bidang industri barang. Data yang diperoleh kemudian dianalisis dan dijabarkan secara deskriptif. Fokus pada penelitian ini adalah proses pengendalian kualitas suatu produk yang dijabarkan secara teoritis.

\section{HASIL DAN PEMBAHASAN}

Pengendalian kualitas statistik merupakan teknik penyelesaian masalah yang digunakan sebagai pemonitor, pengendali, 
penganalisis, pengelola dan memperbaiki proses dengan menggunakan metode metode statistik (Sudjana, 2002). Pengendalian proses statistik merupakan penerapan metode statistik untuk pengukuran dan analisis variasi proses produksi. Dengan demikian timbul variasi kualitas. Ditinjau dari statistik, ada dua macam variasi kualitas yang dikenal, yaitu :

a. Bersifat probabilistik, yakni variasi yang terjadi karena secara kebetulan dan tidak dapat dielakan.

b. Bersifat eratik, yakni variasi yang terjadi tidak menentu dikarenakan timbulnya penyebab tak wajar.

Statistika digunakan dalam proses kontrol kualitas kapan saja dan dimana mungkin. Ada empat macam metode statistik yang dapat digunakan secara terpisah maupun bersamaan atau kombinasi antara mereka.

1. Distribusi Frekuensi Suatu tabulasi atau cacah (tally) yang menyatakan banyaknya suatu ciri kualitas muncul dalam sampel yang dimati. Ini dapat digunakan untuk melihat kualitas sampel secara sepintas, yaitu :
a. Kualitas rata-rata
b. Penyebaran kualitas

c. Perbandingan kualitas spesifikasi yang diinginkan

dengan

2. Gambar Kontrol Menyajikan secara grafik keadaan produksi secara kronologis (jam per jam atau hari per hari) dengan batas-batas yang menggambarkan kemampuan produksi waktu yang lalu. Jika kurva yang dihasilkan melampaui batas-batas yang ada, maka suatu perubahan atau penyesuaian dalam proses produksi dianjurkan, bahkan mungkin diperlukan suatu penyelidikan lebih mendalam. Ada tiga macam gambar kontrol yakni :

a. Gambar kontrol Shewart untuk ukuran karakteristik kualitas. Gambar kontrol ini disebut gambar untuk variabel atau gambar untuk $\mathrm{X}$ (mean) dan $\mathrm{R}$ (range) dan gambar untuk $X$ (mean) dan $\sigma$ (deviasi standar).

b. Gambar kontrol untuk proporsi atau perbandingan antara banyaknya produk yang cacat dengan seluruh produksi. Gambar kontrol ini sering disebut gambar-p ( $p$-chart). c. Gambar kontrol untuk jumlah yang cacat per unit. Gambar kontrol ini disebut gambar-c (c-chart). Gambar-gambar di atas dapat digunakan pada proses berulang. Proses berulang ini tidak hanya dalam produksi maksimal tetapi juga dalam problem manajemen.

3. Tabel Sampling Tabel yang terdiri dari jadwal untuk pengamatan kualitas biasanya dalam bentuk persentase. Hal ini dilakukan untuk menjamin pencapaian kualitas yang dikehendaki untuk produksi maupun barang kiriman.

4. Metode Khusus Metode ini digunakan untuk kontrol kualitas dalam industri. Analisis yang digunakan secara statistik yang cukup rumit, antara lain korelasi, analisis variance, analisis toleransi dan lain-lain (Praptono 1986:1.4).

Teori umum grafik pengendali ini pertama kali diperkenalkan oleh Dr. Walter Andrew Shewhart dari Bell Telephone Laboratories Amerika Serikat pada tahun 1942, dan grafik pengendali yang dikembangkan menurut asasasas ini kerap kali dinamakan Grafik Pengendali Shewhart, ditunjukan dalam gambar 1. Grafik ini untuk mengetahui apakah sampel hasil observasi termasuk daerah yang diterima (Accepted area) atau daerah yang ditolak (rejected area) (Uriyani, 2009).

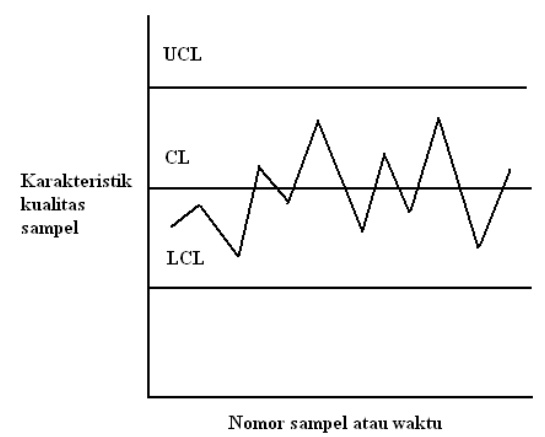

Gambar 1. Grafik Pengendali

Grafik pengendali memiliki sebuah garis tengah dan batas-batas pengendali baik atas maupun bawah. Garis tengah merupakan nilai rata-rata karakteristik kualitas yang berkaitan dengan keadaan terkontrol (yakni, hanya sebab-sebab tak tersangka yang ada). Batas pengendali atas 
(BPA) dan batas pengendali bawah (BPB) dipilih sedemikian hingga apabila proses terkendali, hampir semua titiktitik sampel akan jatuh diantara kedua garis itu. Adapun rumus yang digunakan untuk menentukan BPA adan BPB adalah sebagai berikut :

$$
\begin{aligned}
& B P A=\bar{p}+3 \sqrt{\frac{p_{(1-p)}}{n_{i}}} \\
& B P A=\bar{p}-3 \sqrt{\frac{p(1-p)}{n_{i}}} \\
& \bar{p}=\frac{\sum_{i=1}^{g} x_{i}}{\sum_{i=1}^{g} n_{i}} .
\end{aligned}
$$

Keterangan :

$\bar{p} \quad$ : rata-rata produk cacat pada tiap sampel $x_{i} \quad$ : banyaknya produk yang cacat pada tiap sampel

$n_{\mathrm{i}} \quad$ : banyaknya sampel yang diambil setiap pengamatan/observasi.

(sumber : Uriyani, 2009)

Jika titik-titik terletak di dalam batasbatas pengendali, proses dianggap dalam keadaan terkendali. Ini berarti proses berlangsung atau beroperasi di bawah penyebab wajar sebagaimana diharapkan atau berjalan karena penyebab sistem tetap yang sifatnya probabilistik, dan tidak perlu tindakan apapun. Tetapi, satu titik yang terletak di luar batas pengendali diinterprestasikan sebagai fakta bahwa proses tak terkendali, dan diperlukan tindakan penyelidikan dan perbaikan untuk mendapatkan dan menyingkirkan sebab atau sebab-sebab tersangka yang menyebabkan tingkah laku itu. Meskipun semua titik-titik terletak di dalam batas pengendali, apabila titik-titik itu bertingkah secara sistematik atau tak random, maka ini merupakan petunjuk bahwa proses tak terkendali (Montgomery 1990:121).

Dalam hal pengendalian kualitas suatu produk adapaun metode analisis yang digunakan untuk mengatasi masalah yang ada adalah dengan menerapkan metode statistik. Berikut adalah langkah-langkah implementasi dengan metode tersebut, yaitu:

1. Membuat Check Sheet

Check sheet digunakan untuk mengumpulkan data dan menganalisa data yang telah dikumpulkan sehingga dapat mengetahui permasalahan berdasarkan frekuensi dari jenis atau penyebab dan mengambil keputusan untuk melakukan perbaikan atau tidak. Adapun langkah-langkah adalah sebagai berikut :

a. Mengumpulkan data-data jenis serta jumlah kecacatan yang dialami suatu perusahaan.

b. Menggambarkan cara pencatatan tentang kecacatan yang terjadi pada perusahaan.

c. Membuat usulan Check Sheet yang lebih baik kepada perusahaan.

2. Membuat Diagram Pareto

Diagram pareto dibuat untuk mengindetifikasi, mengurutkan dan bekerja untuk menyisihkan kerusakan produk secara permanen. Diagram pareto merupakan suatu gambar yang mengurutkan klasifikasi datadari kiri kekanan menurut urutan rangking tertinggi hingga terendah. Diagram pareto juga dapat mengidentifikasi masalah yang paling penting yang mempengaruhi usaha perbaikan kualitas dan memberikan petunjuk dalam mengalokasikan sumber daya yang terbatas untuk menyelesaikan masalah. Diagram pareto juga dapat digunakan untuk membandingkan kondisi proses, misalnya ketidaksesuaian proses sebelum dan setelah diambil tindakan perbaikan terhadap proses. Diagram pareto dapat dipergunakan sebagai alat interpretasi, untuk menentukan frekuensi relatif dan urutan pentingnya masalah-masalah atau penyebab-penyebab dari masalah yang ada, memfokuskan perhatian pada isu-isu kritis dan penting melalui membuat ranking terhadap masalah-masalah atau penyebabpenyebab dari masalah itu dalam bentuk yang signifikan (Ariani 2003:19).

Adapun langkah-langkah dalam pembuatan diagram pareto adalah sebagai berikut.

a. Menentukan masalah yang akan diteliti, mengidentifikasi penyebab-penyebab dari masalah yang akan dibandingkan. Setelah itu melaksanakan pengumpulan data. 
b. Membuat ringkasan daftar atau tabel yang mencatat frekuensi terjadinya masalah yang akan diteliti dan dikumpulkan datanya.

c. Membuat daftar masalah secara berurutan berdasarkan frekuensi terjadinya suatu masalah dimulai dari tertinggi sampai terendah serta menghitung frekuensi kumulatif, persentase dari total kejadian, dan persentasi dari total kejadian secara kumulatif.

d. Menggambar dua buah garis vertical dan sebuah garis horizontal.

e. Membuat histogram pada diagram pareto.

f. Gambarkan kurva kumulatif serta cantumkan nilai-nilai kumulatif di sebelah kanan atas interval setiap item masalah.

g. Memutuskan untuk melakukan tindakan perbaikan terhadap penyebab utama dari masalah yang diteliti.

3. Membuat Control Chart

Control Chart dibuat untuk memonitor dan mengevaluasi apakah proses berada dalam pengendalian kualitas secara statistika atau tidak sehingga dapat memecahkan masalah dan menghasilkan perbaikan kualitas. Menurut Gasperz control chart adalah grafik yang menggambarkan perubahan karakteristik mutu pada periode tertentu yang di dalamnya terdapat batas pengendali yang menyatakan proses terkendali atau tidak (dalam Tanjong, 2013). Bentuk dasar dari peta kontrol merupakan peragaan grafik suatu karakteristik kualitas yang tekah diukur atau dihitung dari sampel terhadap nomor sampel atau waktu. Peta control $p$ digunakan untuk mengukur proporsi ketidaksesuaian (penyimpangan atau sering disebut cacat) dari item-item dalam kelompok yang sedang diinspeksi. Dengan demikian peta kontrol $p$ digunakan untuk mengendalikan proporsi dari produk yang cacat yang dihasilkan dalam suatu proses. Adapun contoh Control Chart disajikan pada Gambar 2.

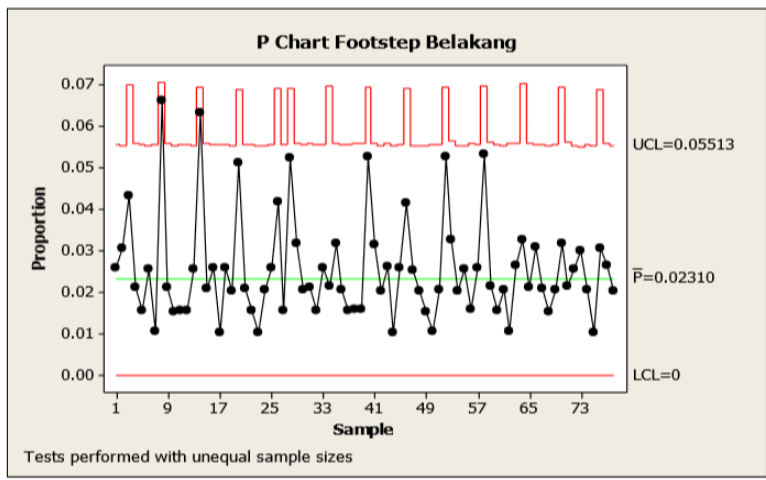

Gambar 2. Contoh Control Chart

4. Diagram Sebab-akibat

Diagram sebab akibat dibuat untuk mencari penyebab terjadinya masalah yang ada atau kecacatan produksi. Diagram sebabakibat digunakan untuk mengidentifikasi faktor-faktor permasalahan yang berpengaruh secara signifikan terhadap output perusahaan. Diagram ini membantu perusahaan untuk mengetahui akar penyebab dari suatu permasalahan. Data pada tahap ini dapat diperoleh dengan cara :

a. Brainstorming dengan pihak perusahaan sehingga dapat diketahui bahwa faktorfaktor mendasar penyebab kecacatan dari faktor manusia, mesin, metode atau lingkungan.

b. Melakukan identifikasi faktor-faktor utama penyebab terjadinya kecacatan, lalu dihubungkan ke cabang panah utama.

c. Melakukan identifikasi terhadap faktorfaktor utama penyebab kecacatan, dan setiap penyebab yang lebih rinci dihubungkan dengan cabang panah (Tanjong, 2013).

Adapun bentuk diaragram sebab akibat disajikan pada Gambar 3. 


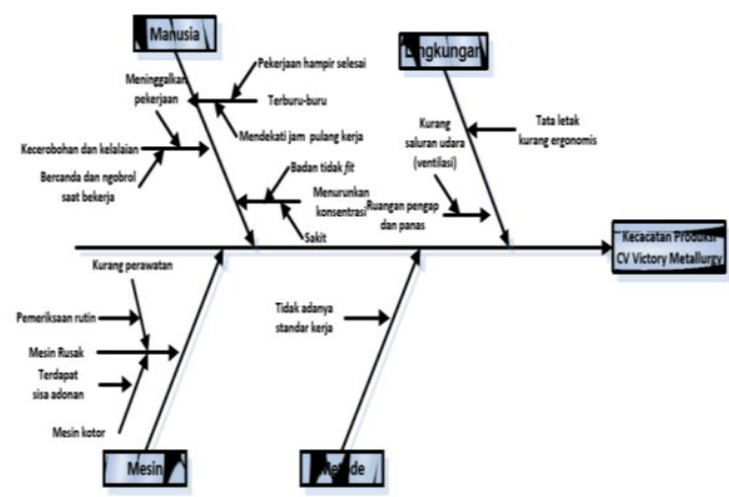

Gambar 3. Contoh Diagram Sebab Akibat

5. Membuat Failure Mode Effect Analysis (FMEA)

Tabel FMEA dibuat untuk mengindentifikasi sebab dan akibat terjadinya permasalahan pokok dan mengukurnya dalam beberapa kriteria standar yang ditetapkan. Tabel FMEA merupakan alat yang digunakan untuk mengidentifikasi sebab dan akibat permasalahan dan melakukan pengukuran berupa nilai-nilai yang berdasarkan pada Severity, Occurance, dan Detection. Tabel FMEA disusun berdasarkan diagram sebabakibat dan kemudian akan ditentukan masalah aman yang akan dijadikan sebagai prioritas untuk ditangani terlebih dahulu.

Langkah-langkah penerapan FMEA :

a. Mengidentifikasi proses produksi

b. Mencatat permasalahan-permasalahan yang dapat timbul pada proses produksi.

c. Memberikan penilaian pada permasalahan-permasalahan tersebut berdasarkan severity, occurance dan detection dengan skala 1-10.

d. Menghitung RPN untuk mrncari permasalahan mana yang akan menjadi prioritas untuk dilakukan tindakan perbaikan terlebih dahulu.

e. Melakukan problem solving berdasarkan prioritas dari nilai RPN (Tanjong, 2013).

\section{PENUTUP}

Dalam sebuah industri, kualitas produk adalah hal yang terpenting agar suatu usaha dapat bertahan dan berkelanjutan. Untuk menjaga kualitas suatu produk perlu adanya kegiatan monitoring terhadap hasil produksi. Proses monitoring tersebut biasanya dikenal dengan instilah quality control atau pengendalian kualitas. Pengendalian kualitas statistik menurut merupakan teknik penyelesaian masalah yang digunakan sebagai pemonitor, pengendali, penganalisis, pengelola dan memperbaiki proses dengan menggunakan metode metode statistik. Adapun langkah-langkah teoritis dalam proses pengendalian kualitas antara lain : 1) Membuat Chech Sheet, 2) Membuat Diagram Pareto, 3) Membuat Control Chart, 4) Membuat Diagram Sebab Akibat, 5) Membuat tabel Failure Mode Effect Anlaysis (FMEA). Pengendalian kualitas dilaksanakan untuk mengetahui seberapa banyak penyimpangan proses/produk hasil produksi yang tidak terkendali. Setelah mengetahui keadaan tersebut melalui FMEA ditentukan hal-hal yang harus dibenahi dan diperbaiki berdasarkan skala prioritas. Dengan menerapkan proses pengendalian kualitas secara rutin dan berkala, tentunya akan berdampak positif terhadap hasil produksi dan kulitas suatu produk akan tetap terjaga.

\section{DAFTAR PUSTAKA}

Ariani, D.W. 2003. Pengendalian Kualitas Statisitik. Yogyakarta : Andi

Kartono, K., 2003. Aplikasi Matematika Dalam Perencanaan Dan Pengendalian Di Bidang Industri. Jurnal Matematika dan Komputer.

Leavenworth, R.S dan Grant, L.E. 1998. Pengendaalian Mutu Statistik. Jilid 1. Alih bahasa: $\mathrm{H}$. Kandahjaya. Jakarta: Erlangga.

Montgomery, D.C. $1990 . \quad$ Pengantar Pengendalian Kualitas Statistik. Alih bahasa: Zanzawi Soejoeti. Yogyakarta: Universitas Gajah Mada.

Praptono. 1986. Buku Materi Pokok Statistika Pengawasan Kualitas. Jakarta: Universitas Terbuka.

Sudjana.2002. Metoda Statistika. Bandung: PT. Tarsito.

Tanjong, S.D., 2013. Implementasi pengendalian kualitas dengan metode statistik pada pabrik spareparts CV Victory Metallurgy Sidoarjo. Jurnal IImiah Mahasiswa Universitas Surabaya, 2(1), pp.1-13.

Uriyani, D., 2009. Pengendalian Kualitas Statistik Pada Proses Produksi Percetakan Buku di CV. Aneka IImu Semarang (Doctoral dissertation, Universitas Negeri Semarang). 